\title{
Immobilization and metabolism of dissolved organic carbon by natural sediment biofilms in a Mediterranean and temperate stream
}

\author{
Tom J. Battin ${ }^{1, *}$, Andrea Butturini ${ }^{2}$, Francesc Sabater ${ }^{2}$ \\ ${ }^{1}$ Department of Ecology, University of Vienna, Althanstr. 14, 1090 Vienna, Austria \\ ${ }^{2}$ Department of Ecology, University of Barcelona, Diagonal 645, 08028 Barcelona, Spain
}

\begin{abstract}
The immobilization and metabolism of dissolved organic carbon (DOC) in natural streambed biofilms from a Mediterranean (La Solana [SOL], Spain) and a temperate (Oberer Seebach [OSB], Austria) stream were investigated using plug-flow bioreactors. Bioreactors were subjected to short-term pulses of allochthonous DOC, i.e. extracted from stream adjacent soils, and of autochthonous DOC, i.e. extracted from stream periphyton. In SOL biofilms, relatively high concentrations of extracellular polymeric substances (EPS) co-occurred with retarded metabolic response to DOC pulses and relatively low respiration rates. In OSB biofilms, however, EPS concentrations were lower and respiration rates were elevated along with immediate metabolic responses to DOC pulses. Furthermore, the uptake rate of DOC from the bulk water increased linearly with the respiration rate in OSB biofilms, yet no such relationship existed in SOL biofilms. Carbon normalized respiration rates $\left(\mu \mathrm{g} \mathrm{O}_{2} \mathrm{mg}^{-1} \mathrm{DOC}\right.$ $\mathrm{h}^{-1}$ ) generally revealed higher metabolic availability of autochthonous DOC than allochthonous DOC in both streams. Cross-feeding experiments (e.g. feeding OSB bioreactors with SOL DOC, and vice versa) revealed higher metabolic availability of terrigenous DOC from OSB than from SOL catchment soils. Cross feeding also suggested that autochthonous DOC from SOL inhibits the metabolism of OSB biofilms. We tentatively propose cyanobacterial toxins as the source of this inhibition. Contrasting patterns of biofilm EPS concentrations, DOC immobilization and metabolism suggest an adaptive response of the microbial biofilm community to major catchment-scale (e.g. climate, vegetation and diagenesis of terrigenous DOC) and channel (e.g. storm frequency and scouring) processes in temperate and Mediterranean streams.
\end{abstract}

KEY WORDS: Streambed biofilms · Dissolved organic carbon $\cdot$ Metabolism $\cdot$ Bioavailability Bioreactors

\section{INTRODUCTION}

The bulk of microbial biomass in headwater streams is associated with sediment biofilms (Geesey et al. 1978) that consist of extracellular polymeric substances (EPS) containing bacteria, to some extent fungi and sometimes also algae (Lock 1993). The heterotrophic biofilm microorganisms commonly satisfy their energy and carbon demand from dissolved organic carbon (DOC) that is immobilized from the porewater by the EPS matrix. Stream DOC consists of a complex pool of

\footnotetext{
•E-mail: tomba@pflaphy.pph.univie.ac.at
}

molecules along an oxidation continuum and can best be described in terms of its chemical composition and bioavailability (e.g. Sun et al. 1997, Volk et al. 1997). Its chemical composition largely reflects catchment and channel processes that, along with flow paths and seasonality, determine the contribution of DOC from different sources (allochthonous vs autochthonous). For instance, at peak primary production algal exudates can substantially contribute to the DOC pool (Kaplan \& Bott 1982) and are recognized as highly available to heterotrophic bacteria (e.g. Cole 1982, Kaplan \& Bott 1989). On the other hand, terrigenous DOC enters streams predominantly during storms (e.g. Kaplan \& Newbold 1993) and is often rich in humic substances 
and their precursors. Although they have commonly been considered to be recalcitrant (e.g. Moran \& Hodson 1990, Leff \& Meyer 1991), Volk et al. (1997) recently demonstrated that humic substances substantially contribute to stream biodegradable DOC.

In contrast to planktonic communities, carbon processing by natural microbial biofilms has received little attention to date. Early field experiments showed that benthic microbial communities can retain considerable amounts of DOC (e.g. Kuserk et al. 1984, McDowell 1985) and bacterial uptake and growth efficiency depend on the DOC source (Kaplan \& Bott 1983). Kaplan \& Bott (1985) and McArthur et al. (1985) provided the first evidence that stream bacteria become acclimated to given sources of DOC. Freeman \& Lock (1992) showed that high molecular weight fractions of DOC can inhibit biofilm metabolism in brown-water rivers. More recently, Freeman \& Lock (1995) described the biofilm matrix as a storage site for organic substrates that prevents heterotrophic bacteria from starvation during times of low carbon supply.

These apparent relationships between DOC sources and sediment biofilm functioning prompted us to postulate that streambed biofilm structure, and hence the immobilization of DOC and its subsequent metabolism, reflects major catchment-scale and channel processes. Streambed biofilms from a Mediterranean and a temperate stream were fed with allochthonous and autochthonous DOC in plug-flow bioreactors. In particular, we addressed the following questions: (1) What is the metabolic responsiveness of these biofilms to short-term DOC pulses from the respective stream ecosystems? (2) What is the relationship between the immobilization and respiration rates? and (3) How do sources (i.e. allochthonous vs autochthonous) of DOC influence its bioavailability to heterotrophic microorganisms in both streams?

\section{MATERIAL AND METHODS}

Site description. Sediment biofilms and DOC originated from the 2 nd order streams of La Solana (SOL), Spain, and Oberer Seebach (OSB), Austria. SOL is located in the SE Pyrenees, north of Barcelona, and drains the Ter River watershed. The SOL catchment has an area of ca $16 \mathrm{~km}^{2}$ and covers an altitude from 500 to $980 \mathrm{~m}$ above sea level (a.s.l.) OSB is located in the karstic pre-Alps, southwest of Vienna, and drains a catchment of $\mathrm{ca} 20 \mathrm{~km}^{2}$ at an altitude ranging from 600 to $1000 \mathrm{~m}$ a.s.1.

The climate in SOL is typically Mediterranean with an annual precipitation of $837 \mathrm{~mm}$ and average air temperature of $13^{\circ} \mathrm{C}$. Prolonged summer baseflow $<30$ I $\left.\mathrm{s}^{-1}\right)$ and sporadic spring and winter storms $\left(>100 \mathrm{l} \mathrm{s}^{-1}\right)$ characterize the SOL hydrologic regime. The climate in OSB is temperate with an annual precipitation averaging $1629 \mathrm{~mm}$ and air temperature ranging from -25 to $33^{\circ} \mathrm{C}$. The hydrograph is flashy with a distinct snowmelt peak in spring and frequent storms (up to 4000 l $\mathrm{s}^{-1}$ ) throughout the year. The hyporheic sediment is calcareous with calcite and dolomite moieties, and grain size is characterized by coarse sand and gravel in both streams. Stream water temperature averages 12.4 and $6.8^{\circ} \mathrm{C}$ in SOL and $O S B$, respectively.

In SOL, stream water DOC concentrations range from 1.5 to 4 and 4 to $8 \mathrm{mg} \mathrm{Cl}^{-1}$ at low and high flow, respectively; hyporheic DOC concentrations vary considerably (1.7 to $33.3 \mathrm{mg} \mathrm{C}^{-1}$ ). DOC concentration in the OSB stream water ranges from 0.73 to $3.5 \mathrm{mg} \mathrm{Cl}^{-1}$, and can increase to $-17 \mathrm{mg} \mathrm{C} \mathrm{l}^{-1}$ during storms; hyporheic DOC concentrations range from 0.88 to $5.7 \mathrm{mg} \mathrm{Cl}^{-1}$. The SOL periphyton community is dominated by the cynobacterial Rivularia sp., and the filamentous Zygnema sp. and Spirogyra sp. (Guasch 1995). In OSB, the periphyton is characterized by the diatoms Gomphonema angustum and Achnanthes minutissima, the green alga Gongrosira incrustans and the cyanobacteria Homeothrix varians and Pleurocapsa spp.

DOC sources. DOC was extracted from near-stream soil (A horizon) samples that were mixed in Milli- $Q$ water $(1: 1, w / w)$ and gently stirred at $4^{\circ} \mathrm{C}$ for $2 \mathrm{~d}$. Periphyton was brushed from gravel, sonicated and resuspended in Milli-Q water. Solutions were centrifuged and the supernatant filtered (Whatman GF/F) and kept frozen $\left(-20^{\circ} \mathrm{C}\right)$ until used in the experiments. Soil and periphyton DOC extracts are referred to as allochthonous and autochthonous DOC throughout the text. Sediment, periphyton and soil samples were collected in SOL and OSB in June and August 1997, respectively.

DOC extracts were concentrated by rotary evaporation (35 to $40^{\circ} \mathrm{C}$ ), and an elemental analyzer (CE Instruments, EA 1110) was used to measure the $C$ and $\mathrm{N}$ content.

Biofilm characterization. Bacterial cells were detached from surfaces by tetrasodium pyrophosphate treatment (0.1 M, $45 \mathrm{~min})$ and subsequent sonication ( $3 \times$ $60 \mathrm{~s}, 50 \mathrm{~W}$ output). The bacterial abundance was determined by epifluorescence microscopy from DAPIstained cells (Porter \& Feig 1980). The polymeric fraction of colloidal carbohydrates is considered to be microbial EPS and was extracted as described by Underwood et al. (1995). Total EPS was assayed by the phenol-sulfuric acid method (Dubois et al. 1956) and uronic acids were measured according to Filisetti-Cozzi \& Carpita (1991).

Experimental apparatus and design. Plug-flow bioreactors (Fig. 1) were prepared and handled as described in Kaplan \& Newbold (1995). They were constructed from Chromaflex chromatography columns (Kontes, Vineland, NJ) (i.d. $=2.4 \mathrm{~cm}$, length $=33 \mathrm{~cm}$ ) 


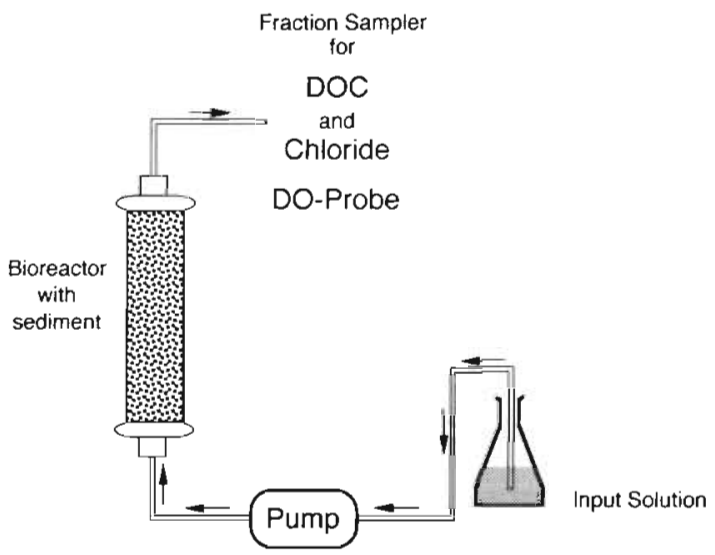

Fig. 1. Experimental bioreactor set-up. See Materials and methods' for details

with polyethylene bed support and connected with PTEF tubing to a peristaltic pump that allows adjustment of the throughflow rate.

In order to assure an intact and natural biofilm, surficial sediment was collected (5 to $20 \mathrm{~cm}$ depth) and gently sieved in the field (June/July 1997); the 0.25 to $2 \mathrm{~mm}$ grain size was retained and re-exposed in perforated columns (in the dark) to hyporheic water flow for 4 to $6 \mathrm{wk}$. Once in the laboratory, the sediment was kept aerated in $10 \mathrm{l}$ jars and processed within $4 \mathrm{~d}$ Bioreactors were packed with approximately $200 \mathrm{~g}$ sediment and care was taken to avoid air pockets. They were kept in the dark at room temperature $(21.2$ $\pm 1.2^{\circ} \mathrm{C}$ ). Prior to each experiment, they were perfused for ca $2 \mathrm{~d}$ with unfiltered water from the stream they were taken from. Inflow water was aerated and maintained at $8.2 \pm 0.6 \mathrm{mg} \mathrm{O}_{2} \mathrm{l}^{-1}$.

The experimental solutions consisted of filtered (Whatman GF/F) streamwater that was spiked with the appropriate DOC solution to a final concentration of ca 5 to $6 \mathrm{mg} \mathrm{Cl}^{-1}$ and with $\mathrm{NaCl}$ as conservative tracer (ca 10\% above background concentration). The duration of all additions was $90 \mathrm{~min}$, except for controls (60 min). Effluent water was collected with a fraction sampler ( 4 to $5 \mathrm{~min}$ interval) and assayed for DOC and chloride concentration within $24 \mathrm{~h}$. DOC was analyzed with a Shimadzu TOC-5000 analyzer at the University of Vienna and with a Skalar SK12 analyzer at the University of Barcelona. Chloride concentration was measured by capillary electrophoresis (Waters, CIAQuanta 5000). Dissolved oxygen (DO) concentration was determined on-line (Clark electrode, WTW OXI 196) at 1 min intervals and recorded with a data-logger. The relative precision of the probe was $\pm 1 \%$ (coefficient of variation).

In a first set of experiments, we perfused SOL and OSB bioreactors with allochthonous and autochthonous
DOC from the respective streams (indigenous DOC). A second experimental set consisted of cross feeding SOL bioreactors with OSB DOC, and vice versa.

DOC immobilization and respiration. We operationally defined DOC immobilization as the flux of DOC from the bulk liquid to biofilms, and calculated it as the product of the uptake rate $(k)$ and the mass DOC in the bioreactor. The 1-dimensional advection-dispersion and transformation equation (e.g. Misra et al. 1974) was used to simulate the temporal dynamics of DOC concentration and to estimate the uptake rate (s). In terms of DOC or chloride concentrations in the bioreactor porewater, the equation can be written as

$$
\frac{\delta C}{\delta t}=D \frac{\delta^{2} C}{\delta x^{2}}-v \frac{\delta C}{\delta x}-k C
$$

where $C$ is the DOC or chloride concentration $\left(\mathrm{mg} \mathrm{l}^{-1}\right)$, $D$ is the hydrodynamic dispersion coefficient $\left(\mathrm{cm}^{2} \mathrm{~h}^{-1}\right)$, $v$ is the water flow velocity $\left(\mathrm{cm} \mathrm{h}^{-1}\right)$, and $k$ is the uptake rate $\left(\mathrm{h}^{-1}\right) . k$ refers to biotic and abiotic adsorption of solutes from the liquid phase by biofilms and mineral surfaces.

The appropriate initial and boundary conditions are

$$
\begin{array}{ll}
C_{(x, 0)}=0 & x>0 \\
C_{(0, t)}=C_{0} & 0 \leq t \leq T_{\text {In })} \\
C_{(0, t)}=0 & t>T_{\text {inj }}
\end{array}
$$

where $C_{0}$ is the carbon input concentration and $T_{\text {in }}$ the duration of the experimental addition. Eq. (1), subjected to these initial and boundary conditions, was solved using Laplace transforms (Misra et al. 1974). We used the chloride $(k=0)$ breakthrough curves to simulate the theoretical DOC output concentration and to estimate the model parameters (Table 1) according to Yamaguchi et al. (1989).

The mass of DOC retained within a given bioreactor was computed from the difference between the observed and expected breakthrough curves. Fig. 2 illustrates the expected and observed DOC breakthrough curves along with the simulated curves for OSB biofilm perfused with autochthonous DOC from OSB

The expected DOC output concentration without transformation at the sediment interface was calculated from

$$
C_{\mathrm{DOC}}^{\text {out }}=C_{\mathrm{Cl}}^{\text {out }} \frac{C_{\mathrm{DOC}}^{\text {in }}}{C_{\mathrm{Cl}}^{\mathrm{ir}}}
$$

where $C^{\text {nn }}$ and $C^{\text {out }}$ refer to input and output concentrations, respectively, of either DOC or chloride. The mass $\left(M_{i}\right)$ of input and output DOC was computed from

$$
M_{\mathrm{j}}=Q \int_{t_{0}}^{t_{0}} C_{\mathrm{j}} \mathrm{d} t
$$

where $Q$ is the water flux $\left(\mathrm{ml} \mathrm{h}^{-1}\right)$ through the bioreactor, $C_{1}$ is the input or output concentration ( $\mathrm{mg} \mathrm{C} \mathrm{l}^{-1}$ ) and $t_{n}$ and $t_{0}$ refer to the duration of the experiment. 
Table 1 Model parameters and mass balance of dissolved organic carbon (DOC) and dissolved oxygen (DO) in biofilm reactors exposed to carbon sources from Lá Solana (SOL) and Oberer Seebach (OSB). Values are represented as mean $\pm S D(n=2)$

\begin{tabular}{|c|c|c|c|c|c|c|}
\hline & $\begin{array}{l}\text { Water } \\
\text { velocity } \\
\left(\mathrm{cm} \mathrm{h} \mathrm{h}^{-1}\right)\end{array}$ & $\begin{array}{l}\text { Ddel paramet } \\
\text { Dispersion } \\
\text { coefficient } \\
\left(\mathrm{cm}^{2} \mathrm{~h}^{-1}\right)\end{array}$ & $\begin{array}{l}\text { Uptake } \\
\text { rate } \\
\left(\mathrm{h}^{-1}\right)\end{array}$ & $\begin{array}{c}\text { Mass DOC } \\
\text { retained } \\
(\mathrm{mg} C)\end{array}$ & $\begin{array}{c}\text { Mass balance } \\
\text { Relative DOC } \\
\text { retention }{ }^{\mathrm{b}, \mathrm{c}} \\
(\%)\end{array}$ & $\begin{array}{c}\text { Mass DO } \\
\text { consumed } \\
\left(\mathrm{mg} \mathrm{O}_{2}\right)\end{array}$ \\
\hline \multicolumn{7}{|l|}{ SOL biofilm } \\
\hline SOL allochthonous DOC & $36.6 \pm 0.85$ & 18.0 & $1.38 \pm 0.08$ & $0.82 \pm 0.10$ & $68.9 \pm 1.1$ & $0.03 \pm 0.004$ \\
\hline SOL autochthonous DOC & $34.2 \pm 2.55$ & 19.5 & $0.87 \pm 0.04$ & $0.85 \pm 0.18$ & $53.2 \pm 6.2$ & $0.24 \pm 0.05$ \\
\hline OSB allochthonous DOC & $32.1 \pm 0.42$ & 12.0 & $0.99 \pm 0.13$ & $0.75 \pm 0.10$ & $68.0 \pm 7.6$ & $0.28 \pm 0.02$ \\
\hline OSB autochthonous DOC & $36.0 \pm 1.70$ & 18.0 & $1.20 \pm 0.08$ & $0.92 \pm 0.05$ & $67.8 \pm 0.6$ & $0.23 \pm 0.01$ \\
\hline \multicolumn{7}{|l|}{ OSB biofilm } \\
\hline OSB allochthonous DOC & $33.0 \pm 1.29$ & 21.0 & $0.75 \pm 0.21$ & $0.61 \pm 0.16$ & $48.5 \pm 13.6$ & $0.46 \pm 0.04$ \\
\hline OSB autochthonous DOC & $31.8 \pm 1.24$ & 21.0 & $1.14 \pm 0.08$ & $0.60 \pm 0.02$ & $68.7 \pm 3.4$ & $0.77 \pm 0.02$ \\
\hline SOL allochthonous DOC & $36.6 \pm 1.43$ & 18.0 & $0.21 \pm 0.04$ & $0.18 \pm 0.13$ & $20.2 \pm 11.5$ & $0.14 \pm 0.03$ \\
\hline SOL autochthonous DOC & $38.4 \pm 1.51$ & 16.8 & $0.57 \pm 0.04$ & $0.66 \pm 0.08$ & $42.0 \pm 10.4$ & $0.29 \pm 0.01$ \\
\hline \multicolumn{7}{|c|}{$\begin{array}{l}{ }^{2} \text { Relating to pre-plateau and plateau conditions } \\
{ }^{b} \text { Relative DOC retention for control treatments were: SOL biofilm SOL allochthonous DOC } 10.0 \% \text {, autochthonous DOC } \\
13.8 \% ; \text { OSB biofilm allochthonous DOC } 10.5 \% \text {, OSB autochthonous DOC } 5.7 \% \\
{ }^{\mathrm{C}} \text { Relative to the input mass DOC }\end{array}$} \\
\hline
\end{tabular}

The mass of oxygen consumed was also calculated from Eq. (6) but with time constraints $t_{0}$ and $t_{n}$, which refer to the start of the addition and the end of the plateau, respectively. We excluded the post-plateau increasing limb of the DO curve from calculations since pronounced tailing occurred in some cases (Fig. 3). The respiration rate was computed from the mass of

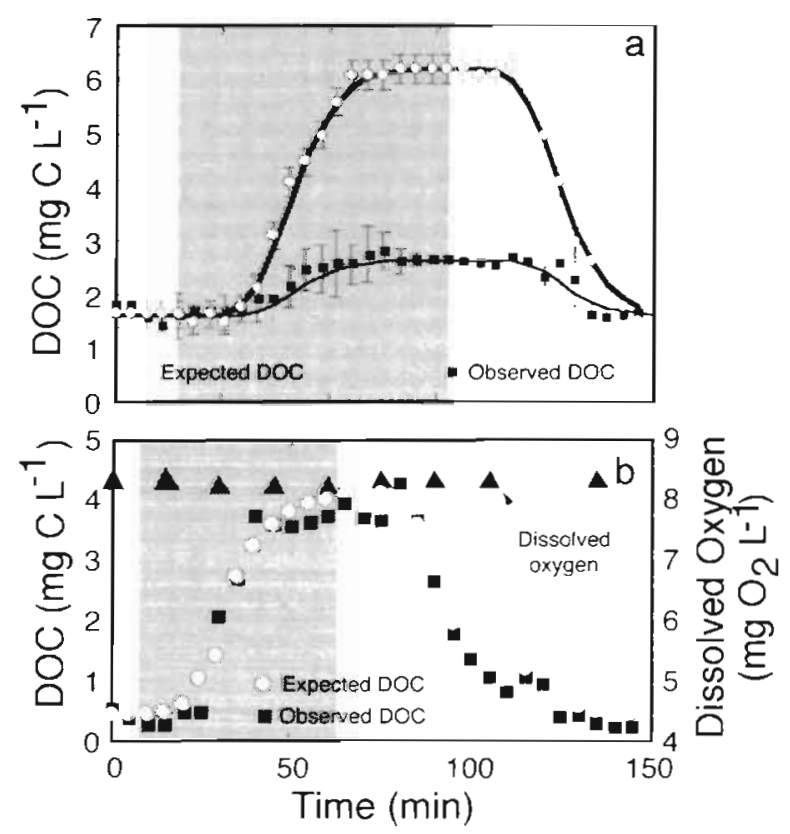

Fig. 2. Breakthrough curves of expected and observed DOC concentrations for OSB (Oberer Seebach, Austria) biofilm exposed to autochthonous DOC from OSB. (a) Experimenta.l and (b) control treatment. Shaded areas designate the duration of the addition. Symbols represent (a) means $\pm \mathrm{SD}_{i}$ (b) means $(\mathrm{n}=2)$. Triangles in (b) refer to dissolved oxygen oxygen consumed and related to the time period $t_{0}$ to $t_{n}$. It is thus understood as an instantaneous metabolic reaction to the carbon pulse. All mass-balance calculations were corrected for baseline concentrations. Mass-balance results are summarized in Table 1.

From these model parameters and mass-balance calculations we derived the metabolic parameters summarized in Table 2. We defined the transient storage of carbon as the difference between the immobilization (input) and the respiration (output) rates. The carbon normalized respiration rate $\left(\mu \mathrm{g} \mathrm{O} \mathrm{O}_{2} \mathrm{mg}^{-1} \mathrm{DOC} \mathrm{h}^{-1}\right)$ is the respiration rate per unit mass of $\mathrm{DOC}$ in the bioreactor corrected for the stream water baseline DOC. We consider this ratio as an adequate measure for the metabolic availability of DOC (cf. Amon \& Benner 1996). An $R Q=1$ was assumed for these calculations.

The relative metabolic response of biofilms is expressed as the slope of the decreasing limb of the oxygen curve as induced by the DOC pulse. We fitted the curvilinear model $y=a+b \times \log (x)$ to the time series where $y$ corresponds to the DO concentration and $x$ to the experimental time. High slopes relate to fast metabolic response, and vice versa. Slopes were computed. with the nonlinear MODEL module of SYSTAT (Wilkinson. 1992). When necessary, we used t-tests to compare slopes between treatments (Fowler \& Cohen 1990).

Two replicates per experimental treatment were performed and 35 to 40 measurements of DOC and chloride (out of 10 to 12 during plateau conditions, see Fig. 2) were done per experiment. All values are given as mean \pm SD. Where within- and among-treatment variation was large, we used the Student's t-test (df, degree of freedom, is 2 , if not otherwise indicated). Significant differences were determined at $\alpha=0.05$. 


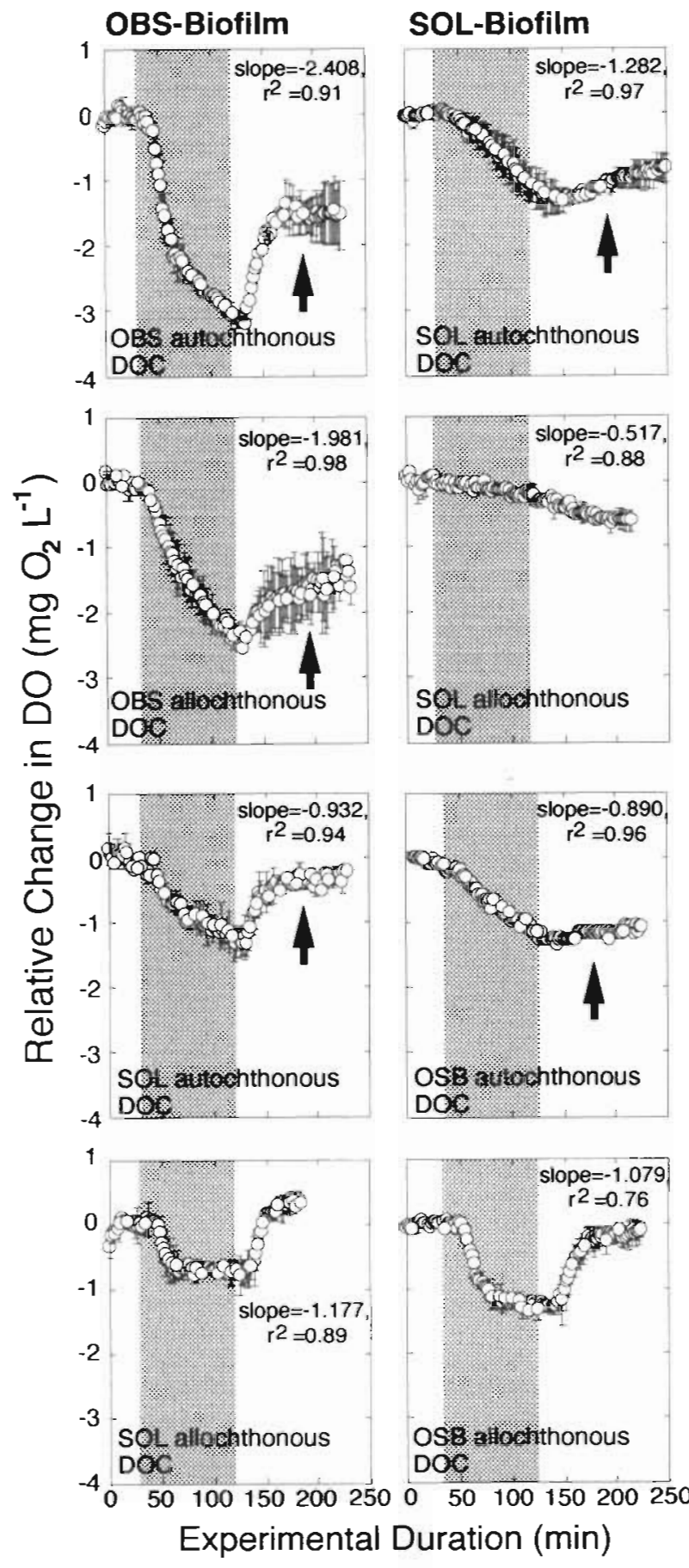

Fig. 3. Metabolic response of biofilms to different sources of DOC. Shaded areas designate the duration of the addition. Symbols represent means $\pm \mathrm{SD}(\mathrm{n}=2)$; when error bars are not shown, the SD was less than the symbol width. Arrows indicate the post-addition plateau. See 'Materials and methods' for further explanations. OSB: Oberer Seebach, Austria; SOL: La Solana, Spain

Controls. We ran 1 control experiment per sediment type and indigenous carbon source to account for abiotic DOC retention (Fig, 2). In a first attempt, com- busted sediment yielded unusually high DOC retention, which we related to altered surface texture as a result of the heat $\left(450^{\circ} \mathrm{C}, 4 \mathrm{~h}\right)$. We then autoclaved $\left(120^{\circ} \mathrm{C}, 60 \mathrm{~min}\right)$ sediment and added sodium azide to the input solutions. Prior to being packed into bioreactor columns, sediment was thoroughly rinsed with Milli-Q water to prevent DOC leaching from particulate carbon (cf. MCDowell 1985). DOC and DO concentrations were monitored and processed as described above.

Control bioreactors retained on average $10.0 \pm 3.3 \%$ (Table 1) of the input mass and stable DO concentration confirmed the absence of heterotrophic metabolism (Fig. 2). We relate this retention predominantly to sorption of DOC molecules to mineral surfaces and, to some extent, to the heat-degenerated matrix.

\section{RESULTS}

\section{Biofilm and DOC characterization}

Bacterial abundance was ca 3.3-fold higher in SOL biofilms (see Table 3). Concomitantly, bulk EPS and uronic acids were also higher in the SOL sediments. C:N ratios of autochthonous DOC were 7.7 and 39.5 for OSB and SOL, respectively, and 12.7 and 21.6 for allochthonous DOC from OSB and SOL, respectively.

\section{Metabolic response and dynamics}

Biofilm metabolism differed in OSB and SOL when exposed to autochthonous and allochthonous DOC (Fig. 3). Indigenous DOC pulses triggered metabolic responses that were 1.9 to 3.8 times higher in OSB than in SOL biofilms. In OSB biofilms, a fast response at the start of the addition co-occurred with pronounced recovery of the oxygen curve at the end of the DOC pulse. The metabolic responsiveness of SOL biofilms was generally more inert with low initial response and almost no recovery after DOC pulses ended, except for the perfusion with allochthonous DOC from OSB (Fig. 3). Cross-feeding experiments with autochthonous DOC did not yield significantly different slopes $(t=1.483, \mathrm{df}=238, \mathrm{p}>0.05)$ between OSB and SOL biofilms, whereas crossing allochthonous DOC did affect $(t=3.092, \mathrm{df}=92, \mathrm{p}<0.01$ ) the metabolic response.

Similar to these response patterns, respiration rates were significantly higher in OSB than in SOL biofilms when perfused with indigenous allochthonous ( $t=$ 13.245, $p<0.01)$ and autochthonous DOC $(t=9.796$, $p<0.05$ ) (Table 3 ). This obviously contrasts with the immobilization rates of $\mathrm{DOC}$, which were $\sim 1.6$ times 
Table 2. Metabolism of biofilms from La Solana (SOL) and Oberer Seebach (OSB) and availability of dissolved organic carbon (DOC) from autochthonous and allochthonous sources. Given are means $\pm S D(n=2)$. DM: dry mass sediment

\begin{tabular}{|c|c|c|c|c|c|}
\hline & $\begin{array}{l}\text { Immobilization } \\
\text { rate } \\
\left(\mu g \mathrm{Cg}^{-1} \mathrm{DM} \mathrm{h}^{-1}\right)\end{array}$ & $\begin{array}{l}\text { Respiration } \\
\text { rate } \\
\left.\mathrm{g} \mathrm{O}_{2} \mathrm{~g}^{-1} \mathrm{DM} \mathrm{h}^{-1}\right)\end{array}$ & $\begin{array}{l}\text { Fraction of } \\
\text { DOC metabolized } \\
(\%)\end{array}$ & $\begin{array}{c}\text { Transient DOC } \\
\text { storage } \\
\left(\mu \mathrm{DOC} \mathrm{g} \mathrm{DM} \mathrm{h}^{-1}\right)\end{array}$ & $\begin{array}{l}\text { Carbon normalized } \\
\text { respiration rate } \\
\left(\mu \mathrm{O} \mathrm{O}_{2} \mathrm{mg}^{-1} \mathrm{DOC} \mathrm{h}^{-1}\right)\end{array}$ \\
\hline \multicolumn{6}{|l|}{ SOL biofilm } \\
\hline SOL allochthonous DOC & $3.14 \pm 0.96$ & $0.08 \pm 0.01$ & $0.96 \pm 0.17$ & $3.11 \pm 0.96$ & $0.92 \pm 0.06$ \\
\hline SOL autochthonous DOC & $3.31 \pm 0.49$ & $0.53 \pm 0.09$ & $6.04 \pm 0.10$ & $3.11 \pm 0.46$ & $4.19 \pm 0.59$ \\
\hline OSB allochthonous DOC & $2.11 \pm 0.60$ & $0.53 \pm 0.04$ & $9.75 \pm 2.01$ & $1.91 \pm 0.59$ & $8.69 \pm 0.46$ \\
\hline OSB autochthonous DOC & $2.60 \pm 0.01$ & $0.45 \pm 0.02$ & $6.42 \pm 0.26$ & $2.43 \pm 0.01$ & $5.65 \pm 1.16$ \\
\hline \multicolumn{6}{|l|}{ OSB biofilm } \\
\hline OSB allochthonous DOC & $2.23 \pm 0.68$ & $0.82 \pm 0.08$ & $14.26 \pm 2.99$ & $1.93 \pm 0.65$ & $9.13 \pm 0.69$ \\
\hline OSB autochthonous DOC & $1.87 \pm 0.51$ & $1.31 \pm 0.07$ & $27.11 \pm 6.03$ & $1.38 \pm 0.48$ & $29.07 \pm 4.34$ \\
\hline SOL allochthonous DOC & $0.49 \pm 0.03$ & $0.25 \pm 0.05$ & $19.46 \pm 5.14$ & $0.39 \pm 0.05$ & $2.63 \pm 0.41$ \\
\hline SOL autochthonous DOC & $1.60 \pm 0.04$ & $0.52 \pm 0.03$ & $12.12 \pm 0.49$ & $1.41 \pm 0.02$ & $4.42 \pm 0.51$ \\
\hline
\end{tabular}

lower in OSB than in SOL biofilms. Differences were, however, not statistically significant for allochthonous $(t=1.089, \mathrm{p}>0.05)$ or for autochthonous DOC $(t=2.876, \mathrm{p}>0.05)$. The fraction of DOC respired during the experimental period ( $230 \mathrm{~min})$ was apparently low and ranged from ca 1 to 10 and 12 to $27 \%$ of the DOC immobilized by SOL and OSB biofilms, respectively (Table 2 ). This translates into considerable transient storage of carbon in the EPS matrix that ranged from 1.91 to 3.11 and 0.39 to $1.93 \mu \mathrm{g} \mathrm{DOC} \mathrm{g}{ }^{-1}$ dry mass sediment (DM) $\mathrm{h}^{-1}$ in SOL and OSB biofilms, respectively. Pooling all treatments with indigenous DOC yielded significant $(t=$ 3.500, $\mathrm{p}<0.05, \mathrm{df}=6$ ) differences of transient storage between SOL and OSB biofilms.

In OSB biofilms, there was a linear relationship $\left(y=-0.077+2.015 x, r^{2}=0.94, p<\right.$ $0.001)$ between uptake $(k)$ and respiration rates along the spectrum of different DOC

Table 3. Characterization of sediment biofilms from Oberer Seebach (OSB) and La Solana (SOL) used in the bioreactors. DM: dry mass sediment

\begin{tabular}{|c|c|c|}
\hline \multirow{2}{*}{ Parameter } & \multicolumn{2}{|c|}{ Biofilm } \\
\hline & OSB & SOL \\
\hline $\begin{array}{l}\text { Bacterial abundance } \\
\left(10^{8} \times \text { cells } g^{-1} \text { DM }\right)\end{array}$ & $2.33 \pm 0.25$ & $7.74 \pm 0.66$ \\
\hline $\begin{array}{l}\text { Total carbohydrates } \\
\left(\mu g C g^{-1} D M\right)\end{array}$ & $8.72 \pm 1.52$ & $12.37 \pm 1.51$ \\
\hline $\begin{array}{l}\text { Uronic acids } \\
\left(\mu \mathrm{g} \mathrm{C} \mathrm{g}^{-1} \mathrm{DM}\right)\end{array}$ & $3.19 \pm 0.44$ & $4.06 \pm 0.14$ \\
\hline \multicolumn{3}{|c|}{$\begin{array}{l}{ }^{\mathrm{a}} t \text {-test, } \mathrm{p}=0.009, \mathrm{n}=3 \\
{ }^{\mathrm{b}} \text { Kruskal-Wallis } 1 \text {-way ANOVA, } \mathrm{p}=0.01, \mathrm{n}=6 \\
{ }^{\mathrm{c}} \text { Kruskal-Wallis } 1 \text { - way ANOVA, } \mathrm{p}=0.02, \mathrm{n}=6\end{array}$} \\
\hline
\end{tabular}

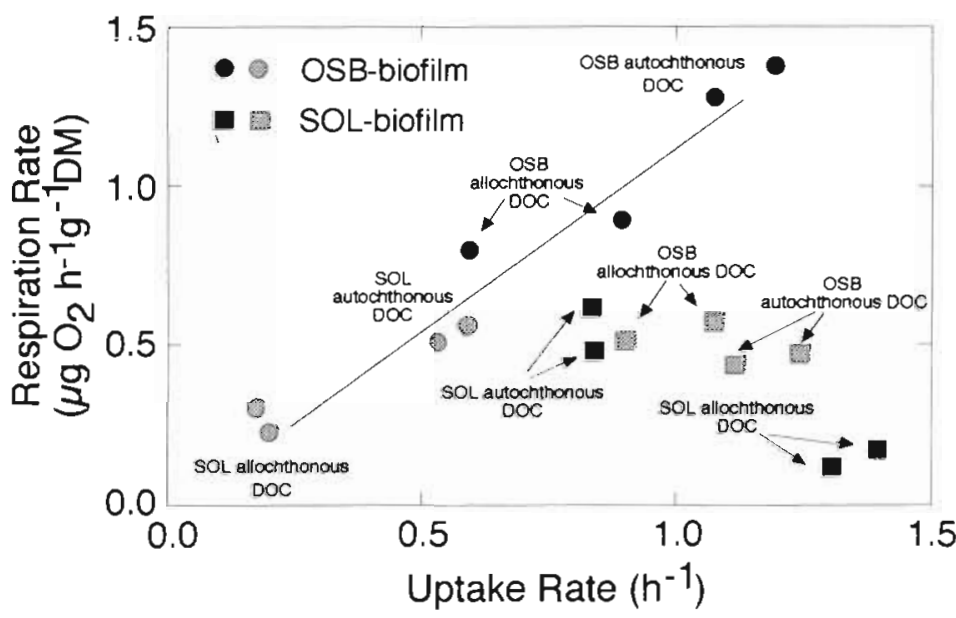

Fig. 4. Relationship between uptake rate $(k)$ and respiration rate for Oberer Seebach (OSB) and La Solana (SOL) biofilms for different DOC sources. Black symbols denote indigenous DOC sources; shaded symbols denote cross-feeding treatments

sources (Fig, 4). Strikingly, no such relationship was found in SOL biofilms. The respiration rate of SOL biofilms varied within a narrow range 10.43 to $0.59 \mu \mathrm{g} \mathrm{O}_{2} \mathrm{~g}^{-1} \mathrm{DM} \mathrm{h}^{-1}$ ), except for the treatment with allochthonous DOC from SOL, whereas the uptake rate ranged from 0.84 to $1.26 \mathrm{~h}^{-1}$. It is important to note that uptake rates were entirely independent of DOC input concentrations (SOL: $r^{2}=0.04, p>0.05$; OSB: $\mathrm{r}^{2}=0.23, \mathrm{p}>0.05$ ) and DOC input mass (SOL: $r^{2}=0.04, p>0.05 ;$ OSB: $r^{2}=0.32, p>0.05$.

\section{Metabolic availability of DOC}

The source of indigenous DOC did not affect the immobilization rate or transient storage in OSB and SOL biofilms (Table 2). However, autochthonous DOC 
was more available than allochthonous DOC. The carbon normalized respiration rate was $\sim 4.3(t=7.834$, $\mathrm{p}<0.05)$ and $\sim 6.7$ times $(t=8.586, \mathrm{p}<0.05)$ higher for autochthonous than for allochthonous DOC in SOL and OSB biofilms, respectively.

In cross-feeding experiments, the OSB immobilization rate remained unaffected $(t=0.730, \mathrm{p}>0.05)$. However, the carbon normalized respiration rate was $\sim 6.6$ times lower $(t=7.988, p<0.05)$ when bioreactors were fed with autochthonous DOC from SOL (Table 2). Autochthonous DOC from OSB, however, did not affect ( $t=1.595, \mathrm{p}>0.05$ ) the SOL biofilm metabolism. Furthermore, cross-feeding experiments revealed low metabolic availability of allochthonous DOC from SOL. DOC from OSB soil dramatically increased (factor 9.4) the carbon normalized respiration rate of SOL biofilms. Allochthonous DOC from OSB also increased (ca 10 times) the fraction of DOC metabolized by SOL biofilms, whereas allochthonous DOC from SOL significantly $(t=11.412, \mathrm{p}<0.01)$ decreased the metabolism of OSB biofilms (Table 2).

\section{DISCUSSION}

\section{DOC processing by streambed biofilms}

Our data are the first to relate matrix EPS to the immobilization and metabolism of DOC by natural and intact streambed biofilms. High matrix EPS in the Mediterranean SOL biofilms was associated with high DOC immobilization rates, but these biofilms had retarded responses to DOC pulses and low respiration rates. Conversely, EPS concentrations and immobilization rates were low in biofilms from the temperate OSB. However, respiration rates were elevated and the metabolic response was immediate and pronounced in these biofilms.

The distinct linear relationship between the uptake rate and the respiration rate in OSB biofilms strongly suggests that microbial metabolism can significantly regulate the immobilization rate in natural biofilms. The matrix surface is in fact finite and sorption sites are limited. Either desorption or metabolism makes new sorption sites available. Low EPS concentration, which presumably translates into thin biofilms in OSB, reduces the diffusional resistance and, along with high metabolism, can increase the transfer rate of substrates from the matrix surface to embedded cells (cf. Wimpenny \& Kinniment 1995). This would induce high turnover of adsorbed molecules in OSB biofilms. The higher absolute concentrations of uronic acids that confer an overall negative charge to the matrix (Corpe 1970) likely enhance adsorption in SOL biofilms. Moreover, assuming that higher EPS concentration in
SOL biofilms involves a more structured matrix would imply improved eddy diffusion (cf. Stolzenbach 1989) and thereby an increased particle and solute flux with subsequent immobilization. Along with relatively low metabolism, this results in net accumulation of organic substrates in SOL biofilms. This would thus agree with the conception of Freeman \& Lock (1995) that the biofilm matrix functions as a major storage site.

There is suggestive evidence that the biofilm matrix protects bacterial cells against certain compounds such as antimicrobials (cf. Gilbert \& Brown 1995). This would imply a certain metabolic inertia of the microbial community when exposed to substrate pulses. However, our experiments demonstrate the immediacy of the metabolic response of natural streambed biofilms when exposed to relatively low DOC concentrations. As discussed above, low EPS concentrations along with elevated metabolism can contribute to the fast response observed in OSB biofilms. The immediacy of the response also suggests that microorganisms are commonly in a state of reduced metabolism (cf. Kjelleberg et al. 1987) and that DOC pulses enable them to recover from this transient metabolic phase under the oligotrophic conditions prevalent in OSB. The post-addition plateau following the recovery of the oxygen curves (see Fig. 3) points towards the use of stored organic substrates that continue subsidizing the biofilm metabolism after the DOC pulse. This supports the buffer hypothesis (Freeman \& Lock 1995) and is consistent with Fiebig (1997), who found considerable delay in mineralization of radiolabeled amino acids immobilized and subsequently stored in perfusion cores. Our experimental approach allowed us to quantify this transient storage (Table 3), and reveals streambed biofilms as highly efficient in immobilizing and retaining DOC molecules supplied during storms and algal release. Normalized to the EPS-carbon concentration (see Table 1), transient storage of carbon yields $0.252 \pm 0.078$ and $0.251 \pm 0.037 \mu \mathrm{g} \mathrm{C} \mathrm{g}^{-1}$ EPS-C $\mathrm{h}^{-1}$ in SOL biofilm and $0.221 \pm 0.075$ and $0.158 \pm 0.056$ $\mu \mathrm{g} \mathrm{C} \mathrm{g}^{-1}$ EPS-C $\mathrm{h}^{-1}$ in OSB biofilm for indigenous soil and algae-DOC, respectively. This translates into considerable mass retention (Table 2) that is closely bracketed by values reported from field experiments (e.g. Kuserk et al. 1984).

Differences in temperature between in situ and laboratory conditions can be ruled out as a major experimental artefact causing the high responsiveness of OSB biofilms. In fact, if temperature had had a major effect on the metabolic responsiveness, we should have observed significant differences between the slopes of the temporal oxygen curves in the cross-feeding experiments (see Fig. 3). However, no such differences were found, for instance, between OSB and SOL biofilms fed with authochthonous SOL and OSB DOC, respectively. 


\section{Metabolic availability of DOC}

SOL autochthonous DOC yielded almost 7 times lower average carbon normalized respiration rates of OSB biofilms than autochthonous DOC from OSB (Table 2). This suggests inhibitory effects of autochthonous DOC from the Mediterranean stream. In previous experiments (T. J. Battin unpubl. data), we measured bacterial secondary production ([methyl $\left.{ }^{3} \mathrm{H}\right]$ thymidine) and estimated $0.49 \pm 0.18$ and $0.13 \pm 0.08 \mathrm{ng} C$ $\mathrm{g}^{-1} \mathrm{DM} \mathrm{h} \mathrm{h}^{-1}$ for SOL and OSB, respectively, when exposed to organic substrates derived from SOL periphyton. Low production rates along with high respiration rates in OSB biofilms, but similar to those in the more productive SOL biofilms, strongly point towards metabolic stress in OSB microbial communities. Inhibition by algal and particularly by cyanobacterial exudates has been reported from planktonic communities (e.g. Cole 1982, and references therein), where toxins act within phycospheres because of very low ambient concentrations. In biofilms, toxins are likely to act in analogy to the phycosphere, in close proximity to bacterial cells. The periphyton community from SOL is in fact known to produce exudates with specific toxicity ranging from 2.12 in Rivularia sp. to 5.51 TU50 in other cyanobacterial groups (M. A. Puig, CEAB-CSIC, pers. comm.). Very low abundance of invertebrate grazers in SOL, despite substantial biomass of primary producers, is a further piece of evidence of the existence of repellents against herbivory.

Complementarily to the action of toxins, the low bioavailability of the autochthonous DOC from SOL as indicated by high $\mathrm{C}: \mathrm{N}$ ratios can also impede OSB biofilm metabolism. High $\mathrm{C}: \mathrm{N}$ ratios hint at significant polysaccharide contributions from Rivularia sp., which is known to produce copious amounts of gelatinous material (e.g. Guasch 1995). Conversely, autochthonous DOC from OSB was higher in amino acids and notably in alanine, glycine, serine and glutamine ( $T$. J. Battin unpubl. data). Proteinaceous moieties have recently been shown to influence DOC availability and to correlate with growth of riverine bacterioplankton (Sun et al. 1997).

We anticipated higher metabolic availability of DOC extracted from the Mediterranean than from the temperate catchment soils. The Mediterranean climate (relatively low precipitation and high average annual temperature) results in low soil humidity that constrains soil microbial degradation (cf. Aerts 1997). Thus relatively highly available end-products are expected to enter the streambed. However, we found terrigenous DOC from SOL yielding lower metabolic rates than DOC from OSB soils. Elevated concentrations of polyphenolic compounds in many Mediterranean plants (Glyphis \& Puttick 1989) are likely to protect labile moieties from uptake by soil bacteria and, once in the stream, can inhibit biofilm metabolism (see also Koetsier et al. 1997). Biopolymerisation (Hedges et al. 1988) of originally labile compounds can ultimately contribute to the inhibitory effect of SOL DOC. The $\mathrm{C}: \mathrm{N}$ ratio of terrigenous DOC from SOL would in fact support these considerations. Amino acid and carbohydrate concentrations were also lower in terrigenous DOC from SOL (T. J. Battin unpubl. data).

\section{Ecosystem implications on biofilm functioning}

Our cross-system comparison of climatically contrasting streams suggests that major catchment-scale processes can influence biofilm structure (in terms of EPS concentration) and functioning. The input of terrigenous DOC, which we showed to have relatively high metabolic availability and which constitutes the major DOC source to the OSB streambed (Battin 1998), depends on storm runoff (catchment-scale process) and is therefore largely unpredictable. In addition, when frequent storm flows in OSB occur, they scour the streambed (channel process), abrase the biofilm matrix (cf. Blenkinsopp \& Lock 1994) and prevent EPS from accumulating. Thus, low EPS allows biofilm bacteria to immediately respond to these unpredictable carbon pulses, thereby ensuring rapid recovery from transient physiologic phases due to alleviated carbon supply. Conversely, Mediterranean streams experience prolonged low summer flow, which in the absence of physical disturbance (channel process) allows the biofilm matrix to grow. Concomitantly, the input of terrigenous DOC remains low and decomposition pathways of soil organic matter (catchment-scale process) yield DOC with low availability. The autotrophic biomass, however, is considerable (e.g. Romani 1997) and continuous DOC release is presumably the major carbon source in SOL. This autochthonous DOC, which we showed to have low short-term metabolic availability, is stored within the matrix where it can undergo catabolic processing (e.g. extracellular enzymes) prior to bacterial uptake.

Acknowledgements. We thank G. J. Herndl, J. Waringer and 3 anonymous reviewers for constructive comments. This study was supported by the Austrian-Hispanic program Acciones Intergradas 29/96 and 27/97 T.J.B. was supported by a grant from the Austrian Ministry of Science and Research

\section{LITERATURE CITED}

Aerts R (1997) Climate, leaf litter chemistry and leaf litter decomposition in terrestrial ecosystems: a triangular relationship. Oikos 79:439-449 
Amon RMW, Benner R (1996) Bacterial utilization of different size classes of dissolved organic matter. Limnol Oceanogr $41: 41-51$

Battin TJ (1998) Biogeochemistry and fluxes of dissolved organic carbon and its metabolism by biofilms in streambeds. PhD thesis, University of Vienna

Blenkinsopp SA, Lock MA (1994) The impact of storm-flow on river biofilm architecture. J Phycol 5:807-818

Butturini A, Battin TJ, Sabater F (1999) Nitrification in stream sediment biofilms: the role of ammonium concentration and DOC quality. Water Res (in press)

Cole JJ (1982) Interactions between bacteria and algae in aquatic ecosystems. Annu Rev Ecol Syst 13:291-314

Corpe WA (1970) An acid polysaccharide produced by primary film forming bacteria. Dev Ind Microbiol 11: $402-412$

Dubois M, Gilles KA, Hamilton JK, Reber PA, Smith F (1956) Colorimetric method for determination of sugars and related substances. Anal Chem 28:350-356

Fiebig DM (1997) Microbiological turnover of amino acids immobilized from groundwater discharged through hyporheic sediments. Limnol Oceanogr 42:763-768

Filisetti-Cozzi TMC, Carpita NC (1991) Measurement of uronic acids without interference from neutral sugars. Anal Biochem 197:157-162

Fowler J, Cohen L (1990) Practical statistics for field biology Open University Press, Philadelphia

Freeman C, Lock MA (1992) Recalcitrant high-molecularweight material, an inhibitor of microbial metabolism in river biofilms. Appl Environ Microbiol 58:2030-2033

Freeman C, Lock MA (1995) The biofilm polysaccharide matrix: a buffer against changing organic substrate supply? Limnol Oceanogr 40:273-278

Geesey GG, Much R, Costerton JW, Green RB (1978) Sessile bacteria: an important component of the microbial population in small mountain streams. Linnol Oceanogr 23 $1214-1223$

Gilbert P, Brown MRW (1995) Mechanisms of the protection of bacterial biofilms from antimicrobial agents. In: LappinScott HM, Costerton JW (eds) Microbial biofilms. Cambridge University Press, p 118-132

Glyphis JP, Puttick GM (1989) Phenolics, nutrition and insect herbivory in some garrigue and maquis plant species. Oecologia 78:259-263

Guasch H (1995) Primary production of epilithic biofilms in Mediterranean streams. PhD thesis, University of Barcelona

Hedges JI (1988) Polymerization of humic substances in natural environments. In: Frimmel $\mathrm{FH}$, Christman RF (eds) Humic substances and their role in the environment. Wiley, New York, p 45-58

Kaplan LA, Bott TL (1982) Diel fluctuations of DOC generated by algae in a piedmont stream. Limnol Oceanogr 27: $1091-1100$

Kaplan LA, Bott TL (1985) Acclimation of stream-bed heterotrophic microflora: metabolic responses to dissolved organic matter. Freshw Biol 15:479-492

Kaplan LA, Bott TL (1989) Diel fluctuations in bacterial activity on streambed substrata during vernal algal blooms: effects of temperature, water chemistry, and habitat. Lim nol Oceanogr 34:718-733

Kaplan LA, Newbold DJ (1993) Biogeochemistry of dissolved organic carbon entering streams. In: Ford TE (ed) Aquatic

Editorial responsibility: Karel Simek,

České Budéjovice, Czech Republic microbiology. An ecological approach. Blackwell, Cambridge, MA, p 139-166

Kaplan LA, Newbold DJ (1995) Measurement of streamwater biodegradable dissolved organic carbon with a plug-flow bioreactor. Wat Res 29:2696-2706

Kjelleberg S, Hermansson M, Mårdén P, Jones GW (1987) The transient phase between growth and nongrowth of heterotrophic bacteria, with emphasis on the marine environment. Annu Rev Microbiol 41:25-49

Koetsier P III, McArthur JV, Leff LG (1997) Spatial and temporal response of stream bacteria to sources of dissolved organic carbon in a blackwater stream system. Freshw Biol 37:79-89

Kuserk FT, Kaplan LA, Bott TL (1984) In situ measures of dissolved organic carbon flux in a rural stream. Can J Fish Aquat Sci 41:964-973

Leff GL, Meyer JL (1991) Biological availability of dissolved organic carbon along the Ogeechee River. Limnol Oceanogr 36:315-323

Lock MA (1993) Attached microbial communities in rivers. In Ford TE (ed) Aquatic microbiology. An ecological approach. Blackwell, Cambridge, MA, p 113-138

McArthur JV, Marzolf GR, Urban JE (1985) Response of bacteria isolated from a pristine prairie stream to concentration and source of soluble organic carbon. Appl Environ Microbiol 49:238-241

McDowell WH (1985) Kinetics and mechanism of dissolved organic carbon retention in a headwater stream. Biogeochem 1:329-352

Misra C, Nielsen DR, Biggar JW (1974) Nitrogen transformation in soil during leaching: I. Theoretical considerations. Soil Sci Soc Am Proc 38:289-293

Moran MA, Hodson RE (1990) Bacterial production on humic and nonhumic components of dissolved organic carbon. Limnol Oceanogr 35:1744-1756

Porter KG, Feig YG (1980) The use of DAPI for identifying and counting aquatic microflora. Limnol Oceanogr 5:943-948

Romani AM (1997) Heterotrophic and autotrophic metabolism in Mediterranean streams. PhD thesis, University of Barcelona

Stolzenbach KD (1989) Particle transport and attachment. In Characklis WG, Wilderer PA (eds) Structure and function of biofilms. Dahlem Workshop Reports. Wiley, New York, p 33-48

Sun L, Purdue EM, Meyer JL, Weis J (1997) Use of elemental composition to predict bioavailability of dissolved organic matter in a Georgia river. Limnol Oceanogr 42:714-721

Underwood GJC, Paterson DM, Parkes RJ (1995) The measurement of microbial carbohydrate exopolymers from interstitial sediments. Limnol Oceanogr 40:1243-1253

Volk CJ, Volk CB, Kaplan LA (1997) Chemical composition of biodegradable dissolved organic matter in streamwater. Limnol Oceanogr 42:39-44

Wilkinson L (1992) SYSTAT for the Macintosh. Evanston, IL

Wimpenny JWT, Kinniment S (1995) Biochemical reactions and the establishment of gradients within biofilms. In: Lappin-Scott HM, Costerton JW (eds) Microbial biofilms. Cambridge University Press, p 99-117

Yamaguchi T, Moldrop P, Yokosi S (1989) Using breakthrough curves for parameter estimation in the convection-dispersion model of solute transport. Soil Sci Soc Am J 53:1635-164

Submitted: September 28, 1998; Accepted: April 13, 1999

Proofs received from author(s): October 1, 1999 